\title{
Challenges and Prospects of E-Learning for Prison Education in Nigeria
}

\author{
Biliamin Adekunle Adeyeye, M.Ed
}

Tai Solarin University of Education, Nigeria

Doi:10.19044/esj.2019.v15n25p327 URL:http://dx.doi.org/10.19044/esj.2019.v15n25p327

\begin{abstract}
Prison education is principally aimed at improving the inmate's skills and employability by means of formal, technical and vocational education to reduce recidivism. Sceptics have argued against the need for educating prisoners who are perceived as condemned, particularly education via the internet. This short conceptual article highlights the strengths and weaknesses of educating prisoners and draws forth the prospects and challenges therein and also assesses how e-learning may have influenced the prisoners to become either educated criminals or a reformed and changed personalities. This paper reports some study findings that were globally shared among academic and non-academic scholars concerning e-learning technologies and its integration in general education practices and prison education in particular through a survey of literature and personal observations. The key conclusion is that prison education has contributed more in reducing recidivism and lesser employability of released prisoners better than when formal education initiative was elusive in the prison service world over.
\end{abstract}

Keywords: E-learning, Prison education, Recidivism, National Open University, Nigeria Prison Service, Nigeria

\section{Introduction}

Sceptics of e-learning educational systems have argued that prison education in most cases has produced nothing but better educated and more sophisticated criminals (Ekpenyong \& Undutimi, 2016). The feelings that exposing prisoners to a technological form of learning and having opportunity to learn and access the internet at their own convenience and all by themselves will further make their criminal mind grow sophisticated and aid them more in committing crimes using the state fund and resources against the state.

However, evidence abounds in the literature showing that prison education has helped many prison inmates to be fully reformed and gainfully employed so as to stay out of jail and crime life. This has contributed 
immensely to the reduction in recidivism and help the society grow (Alexandria, 2016; Ekpenyong \& Undutimi, 2016; Ogbaka, Ewelum, \& Apiti, 2017; Prison Study Project (PSP), 2019).

\section{Background}

Nigerian prisons over the years have been enormously characterized by some problems and dark histories, which several studies have affirmed to be the rationale for the inadequacies of the system to function well as a correction institution (Obioha, 2011). The Nigerian Prison Service (NPS) had since taken several practical steps towards the reformation and rehabilitation of the prisons and the prison inmates. Among such steps was the educational collaboration of the Nigeria Prison Services (NPS) with the National Open University of Nigeria (NOUN). The NOUN through its management and Senate, established special study centers in some of the nation's prisons and declared free education for prisoners as part of NOUN's mission to be a pacesetter institution for educational access delivery, and her collaborative effort to support the government and the Nigerian prison service in their advocacy for widening educational access and helping prisoners to acquire formal education and improved quality of life (NOUN, 2017).

Prison education in Nigeria prior to the establishment of NOUN special training centers at six different Nigerian prisons in the year 2016 was based on the provision of informal education in form of apprenticeship in trades necessary to keep prisoners operational. Reformation programmes of the Nigerian prison were designed to equip prison inmates with the vocational skills and knowledge that will help them to settle down in some vocations on their release back to society. According to Ogbaka et al. (2017), this was predicated on the assumption that most people commit crimes due to lack of a legitimate means of livelihood. They added that the fundamental essence of vocational training in prison is to help prisoners develop skills that are marketable for job acquisition after being released from prison back to society. It is believed that this will serve as an instrument of reformation, job empowerment, and change in behaviour. Similarly, from a broader perspective, Crowther (as cited in Ogidan \& Jarri, 2012) reported that roughly half of all prisoners in the United States of America were unemployed at the time of their arrest because the average educational level of a prison inmate on admission to the prison is the 11th grade. It was however revealed by Crowther that through access to learning, most of them became equipped with one skill or another that makes them be employable before the expiration of their jail term.

According to the United Nations (UN) (2009), the provision of education furtherance programme is a fundamental basic principle that should be employed for the treatment of prisoners to prepare them for reintegration 
back into the educational system of the society so as to become employable at the end of their jail term. Education is thus viewed as fundamental rehabilitative engagement for prisoners to evolve during incarceration and trial periods. Prison education is broadly viewed to encompass a number of prison activities, which are educationally based. These educationally-based activities include basic literacy programs, secondary school equivalency programs, vocational training, higher academic and general studies. The goals of these activities are to prepare a prisoner for successful adjustment outside the prison.

According to Ogbaka et al. (2017), Prison education is an alternative strategy that will enable the prisoners to leave the prison with more skills and be positioned to be employable at released. Aliyu, Mustaffa, and Nasir (2016) define prison education as "an aspect of lifelong learning which every adult whether 'free' or 'restricted' should be entitled to. They opined that education in prison is necessary because its provision will make the prisons become places of continuous and informal learning rather than "schools of crime" (p.4).

According to Ogundipe (as cited in Ogbaka et al., 2017) Nigerian prisons service as part of its several practical steps has developed pragmatic educational strategies for reforming the prison inmates. These strategies according to him include Vocational Skills Development Programme (VSDP) which aims at empowering prisoners with the needed skills for self-sustenance and actualization. There is also adult and remedial education programmes designed to help prisoners who were formerly engaged in one form of academic engagement or the other before being incarcerated.

On the issue of vocational study programs for prisoners, Ekpenyong and Undutimi (2016) stated that prisoners who participated in vocational training programs while in prison are likely not going to be re-engaged in crimes after release thereby reducing their possibility of return back to prison. The vocational programmes in prisons take numerous forms and ranges from trade building skills, mechanical apprenticeship, carpentry and upholstery work, furniture building, tailoring, and computer application skills. They argued that vocational skills for prisoners afford them legitimate opportunities for job employment after prison life. They also argued that vocational training has been an effective tool for the reduction of recidivism based on evidence from other available researches. On the other hand, Otodo and Ugwuoke (2015) argued that a more rehabilitative means by which the prisoners can be engaged while in prison is through formal education programs. "It is not just a means of keeping the prisoner occupied, but it has the capacity to form a stepping stone towards prisoner's inclusion and reintegration into society" (p.44).

Meanwhile, e-learning is reshaping the conventional means of learning and rapidly forming an integral part of educational deliveries worldwide. The 
rate at which the internet cum technologically related education and online academic programmes are rapidly growing is of high significance. The global market for e-learning is estimated to rise from US\$190 billion in 2018 to US\$300 billion by the year 2025 (Globe Newswire [GN], 2019). The rising global enrolments and the growing application of technology in academic institutes are major factors propelling the continuous expansion of the elearning market. "Among the multiple reasons and motives why institutions engage with e-learning or online learning, widening access, increasing flexibility and cost-effectiveness are the most widely recognized rationale" (Söderström et al. as cited in Cloete, 2017, p.2). The suitability of e-learning for everyone and its digital revolution has brought about remarkable changes in the assessment of educational contents, information sharing and consistency in learning.

Hedge and Hayward (2004), define e-learning as "an innovative approach for delivering electronically mediated, well-designed, learnercentred and interactive learning environments to anyone, anyplace, anytime by utilizing the internet and digital technologies in concern with instructional design principles" (p.46). E-learning according to OECD Centre for Educational Research and Innovation is defined as "the use of information and communication technologies in diverse processes of education to support and enhance learning in institutions of higher education, and includes the usage of information and communication technology as a complement to traditional classrooms, online learning or mixing the two modes" (OECD/CERI, 2005, p.11). In the view of Cope and Kalantzis (2016), it is the use of computing devices that mediate or supplement the relationships between learners and teachers.

The narrative of E-education is all about learning using different electronic appliances and technological gadgets like laptops, desktops, tabs, CD ROMs and sophisticated phones. It involves the use of open resources to deliver teaching and learning, monitoring of learner' performance, administration of tests and exams, and also evaluation of student' performance. Based on the previously identified definitions, Damonse (2003) concluded that "e-learning is used interchangeably with online education" (p.25).

Technology-based e-learning according to Fry (as cited in Valentina \& Nelly, 2014, p.397) "encompasses the use of the internet and other important technologies to produce materials for learning, teach learners, and also regulate courses in an organization". E-learning has been classified in different ways. According to Algahtani (as cited in Valentina \& Nelly, 2014, p.399) "there have been some classifications based on the extent of their engagement in education. Some classifications are also based on the timing of interaction". Algahtani divided e-learning into two basic types, namely the computer-based and the internet-based e-learning. For the purpose of this paper, e-learning is 
understood as encompassing both the computer-based and the internet technologies.

\section{The Lunch of E-learning in the Nigerian Prison}

Aliyu et al. (2016) explained that the prison service in Nigeria since inception, have had little or no systematic ways such as e-learning method through which the prison provides formal education for inmates due to limited resource allocation. They posited that early colonial studies have emphasized the protective functions of the prison generally while silent on correctional education and vocational education that characterized the functions of the modern prison. In lieu of this, a collaborative effort was established between the Nigerian Prison Service and NOUN. This has brought about a change in the narration of systemic educational provision in the Nigerian prison. A distance learning programme initiative was launched at different prisons across the country through the NOUN special prison study centres, many prisoners were registered and enrolled into the programme and many had since graduated from it (Agent-Report, 2018). Emphasizing the importance of open distance form of learning and the use of the internet for education activities, UNESCO (2002) in a study of trends, policy and strategy consideration asserted that:

Open distance learning is one of the most rapidly growing fields of education, and its potential impact on all education delivery systems has been greatly accentuated through the development of internet-based information technologies, and in particular the World Wide Web presenting approaches that focus on opening access to education and training provision, freeing learners from the constraints of time and place and offering flexible learning opportunities to individuals and groups of learners (p.7).

This paper, therefore, examines the prospects and challenges of prison education and how e-learning that utilises internet technologies may have either negatively influence the criminality of prisoners or positively enhance and support effective learning for prisoners undertaking formal and remedial education programmes in prisons through the NOUN open distance education programme. The paper is informed by a literature review that focused on the assessment and evaluation of prison programmes and implications of digital education.

\section{The Prospects and Relevance of Prison Education}

Prison education from both national and international perspectives has shown to be a veritable tool through which recidivism can be reduced. It is a mean to rehabilitate, treat and reform prisoners for reintegration back into the society as law-abiding citizens. "Studies conducted over the last two decades 
almost unanimously indicate that higher education in prison programme reduces recidivism and translates into reductions in crime, savings to taxpayers, and long-term contributions to the safety and well-being of the communities to which formerly incarcerated people return" (PSP, 2019, para.1).

According to Smith (2019), in a report on the benefit of prison education; stated that "expanding access to college prison program could reduce state prison spending. The report found that incarceration cost across states would decrease by $\$ 365.8$ million a year because recidivism rates would likely decrease" (para.5). "A new report by the Vera Institute of Justice and Georgetown Center on Poverty and Inequality that examined the economic benefit of educating incarcerated people recommends lifting the ban on providing federal financial aid to inmates" (para.1). An oft-cited 2013 study by the Rand Corporation, commissioned by the U.S Department of Justice, found that "every dollar invested in prison education programs yielded savings of between four and five dollars during the first three years' post-release. Inmates who participated in education programs had a 43 per cent lower chance of returning to prison than those who did not and were 15 per cent more likely to be employed following their release" (Alexandria, 2016, para.6).

In congruence with the global research outcomes, a study carried out by Otodo and Ugwuoke (2015) on Jos prison in Nigeria, also shows the importance of education to the rehabilitation and reformation of prisoners at the Jos prison. Otodo and Ugwoke argued that the result finding of their study is also in tandem with Gumi's findings (as captured in Otodo \& Ugwoke, 2015) where he posits that formal education in the rehabilitation of prison inmates is cardinal and vital. This result was also correlated with the position of Omoni and Ijeh (2009) who agreed that the entrenchment of vocational studies and systemic formal education in the rehabilitation of prisoners cannot be overemphasized. In summary, it is evident in both the national study outcome and the international reports that there is a unanimous resolution in the findings suggesting the relevance and prospects for prison education and the value and potentials it portends to reduce crime and aid economic prudence and societal development.

\section{The Prospects of E-Learning to Prisoners Education in Nigeria}

Olukayode (2015), in a study on the challenges and prospects of elearning in National Open University of Nigeria (NOUN) found that the majority of the students who undertake remedial educational programs in the NOUN special study centres, in their use of computer-aided materials as medium of study, showed a positive attitude and confessed to the overall impact of e-learning. The students also revealed according to the study that, elearning has motivated them to be self-dependent. Olukayode argued that the 
result of his study is in consonance with Lynch's findings of 2008 (as cited in Olukayode, 2015). The conclusion of the findings established the prospect of e-learning as futuristic, owing to the submission of the majority of the students sampled. E-learning has helped to subdue the problem of shortage of learning resources. This according to Olukayode is in concordance with existing studies such as (Bennett \& Lockyer, 2004; Kompf, 2005; Rogers \& Finlayson, 2004 as cited Olukayode, 2015).

A study by Daley et al. (as cited in Damonse, 2003) established that 'learners' attitudes and perceptions were largely determined by their level of participation in an e-learning environment, and hence had a positive impact on their learning experiences" (p.31). According to Damonse (2003), the study conducted by Summary and Summary (1998) to determine the impact of webbased instruction upon students attitudes and performance also shows that using of internet resources had an influence on the students' attitudes and enhanced their learning experiences (p.32).

Valentina and Nelly (2014) also explained that some studies give the advantage of e-learning as its ability to focus on the needs of individual learners. This statement coincides with the argument of Badar, Mason, and Khan (2018) that learning models based on the use of e-technologies can help in the provision of educational access to people who live in remote areas where schools, teachers and libraries are unavailable. Marc (as cited in Valentina \& Nelly, 2014) engenders the features of focusing on the needs of individual learners as one of the advantages of e-learning in education. He viewed this advantage as an important factor in the process of education rather than on educational institutions' needs.

\section{Challenges of Prison Education and E-Learning Programmes in Nigeria}

The prison education and e-learning programme initiatives in Nigeria is not without its shortfalls and challenges just like conventional education programmes. The implementation of educational programmes in prison, on one hand, is attached to several barriers, impediments, and constraints, which were born out of the fact that prison as an institution, consider security concerns more important than all other goals including education. This has certainly limited the extent to which prison educational program can be exploited. According to Hurry, Brazier and Wilson (as cited in Otodo \& Ugwuoke, 2015) "In prisons, particularly in the United Kingdom, the curriculum is often restricted so that prisoners are expected to engage in education that is focused on improving narrow literacy skills rather than broader, and potentially more attractive, educational areas" (p. 49).

On the other hand, the executors of the prison education programme in most parts of the world particularly Nigeria is primarily faced with the challenges of instructing condemned criminals having a large variance in age, 
discrepancies in educational levels and experience. Another factor of concern in the programme is contending with is the problem of staff shortage and lack of educational resources, the problem of non-availability of dedicated classrooms, inconvenient ambience for study, resent from prison staff, and reluctance of prisoners, overcrowding, and poor prison condition, unfulfilled rehabilitation mandates, lack of funding, and many more factors that are related with socio-economic issues.

Moreover, a couple of prior studies have provided evidence for these assertions: According to Onyekachi (2016, p.4) "available records from the Federal Ministry of Interior indicate that Nigeria prisons are congested". Ndukwe and Iroko, (2014) affirm that, over the years, the provisions of welfare services to inmates in Nigerian prisons have been far from satisfactory. While Muhammad, Gwangndi, and Hassan (2017) argued that, prison conditions in Nigeria have had the most dehumanizing and degrading effect on inmates. In a broader perspective beyond the Nigerian scope, Amnesty International affirms that "Prisons in Africa are overcrowded; compelling prison authorities to intermingle offenders with different crime history in the same cell with reported myriad challenges confronting prison officers" (Amnesty International (AI), 2012). While Aliyu et al. emphasised that "funds are not adequately provided to the Nigerian Prison Service for the procurement of tools, machinery, and other correctional materials and where it is provided no one can give an account of what it was spent on" (Aliyu et al., 2016, p.6).

Furthermore, findings from the study of Olukayode (2015) revealed that NOUN lacks the availability of needed e-learning facilities and resources to take care of the need of the learners across their special study centres such as desktop computers or laptops equivalents, provision of internet facilities, projectors and screens for display, video cameras, compact disks and many more. This according to Olukayode is also in line with the findings of Omofaye (2007) who observed that NOUN does not have the required funding for the acquisition of the needed e-resources. This has grossly affected the execution of adequate learning opportunities for the prisoners leaving them having no equal access to facilities and has contributed to challenges of elearning in terms of its utilization for instructional purposes. This was corroborated by personal interaction with inmates and the desk officer of the NOUN Kirikiri study centre based on observational research and findings from other research works such as (Ajadi, Salawu, \& Adeoye, 2008; Ogidan \& Jarri, 2012).

\section{Conclusion}

Based on the prior findings of earlier studies has highlighted and discussed, and the outcome of this research work, it becomes evident that elearning encompasses more than just the offering of online courses; it includes 
all technological forms of knowledge engagements. Secondly, e-learning has moved from a fully-online course to using technology in the delivery of part or all of a course independently, without any recourse to the need for a fixed time or a fixed place. It has enhanced the participation of learners to become self-motivated and self-dependent. However, e-learning is obviously not an end in itself but a means to it. This implies that the implementation of elearning in prison education cannot take the place of an educator but rather complement it.

It is also observed that despite its growing popularity, e-learning is still less valued than the conventional known traditional learning, particularly for prisoners. Interestingly, the reason for this dissatisfaction is not on the viability of e-learning itself as a process of studying but rather the non-availability of e-resources required for its operation in Nigeria, coupled with the problem of epilepsy power supply and lack of access to fast and cheap internet service provision. This article posits, therefore, that e-learning has helped in the execution and development of learning process in the prison and prison education has, in turn, contributed more to the reduction of recidivism and lesser employability of released prisoners than when formal education initiative was elusive in the prison service world over.

\section{References:}

1. Agent-Report (2018, August 28). Nigerian prison wins $\$ 20,000$ UNESCO prize. Premium-Times Nigeria. Retrieved March 29, 2019 from https://www.premiumtimesng.com

2. Ajadi, T.O., Salawu, I.O., \& Adeoye F.A. (2008). E-learning and distance education in Nigeria. Turkish Online Journal of Educational Technology, 7(4). Retrieved from https://www.files.eric.ed.gov/fulltext/ED503472

3. Alexandria, N. (2016, September, 14). Educating prisoners saves money and lives: Give a brother a chance. Retrieved from http://www.villagevoice.com

4. Aliyu, K.A., Mustaffa, J. \& Nasir, N. (2016). An evaluation of prison educational programmes in Kwara State Nigeria. Retrieved from https://www.researchgate.net/publication/321170665

5. Amnesty International Researchers. (2007). Nigeria: Amnesty International delegates say prison conditions appalling. Retrieved from http://www.amnesty.org/

6. Badar, F., Mason, J., \& Khan, K. (2018). Re-thinking out-of-school learning in rural Pakistan. In J. C. Yang et al. (Eds.) Proceedings of the 26th International Conference on Computers in Education. Philippines: Asia-Pacific Society for Computers in Education. 
7. Cloete, A.L. (2017). Technology and education: Challenges and opportunities. HTS Teologiese Studies/Theological Studies, 73(4), DOI:10.4102/hts.v73i4.4589

8. Cope, B., \& Kalantzis, M. (2016). E-Learning Ecologies: Principles for New Learning and Assessment (eds.). New York NY: Routledge.

9. Damoense, M.Y. (2003). Online learning: Implications for effective learning for higher education in South Africa. Australian Journal of Educational Technology, 19(1), 25- 45.

Retrieved from https://ajet.org.au/index.php/AJET/article/view/1689

10. Ekpenyong, N.S., \& Undutimi, J.D. (2016). Prisons rehabilitation programmes in Nigeria: A study of inmates perception in Okaka prison Bayelsa State. Studies in Sociology of Science, 7(6), 1-12. DOI:10.3968/9104

11. Globenewswire. (2019, March 6). E-learning market to surpass $\$ 300$ bn by 2025: Global market insight, Inc. Retrieved from http://www.gblobenewswire.com/news

12. Hedge, N., \& Hayward, L. (2004). Redefining roles University elearning contributing to lifelong learning in a networked world.

E-Learning Journal,1,128-145.Retrievedfrom http://www.nationmaster.com/country/ni/Internet

13. Marc, J. R. (2002). Book review: e-learning strategies for delivering knowledge in the digital age. Internet and Higher Education, 5, 185188.

14. Muhammad, Y.A., Gwangndi, M.I., \& Hassan, A.S. (2017). The rights of prisoners in Nigeria and the role of prisons and modern penology. Journal of Law, Policy and Globalization. Retrieved from http://www.iiste.org

15. National Open University of Nigeria. (2017). NOUN Approves free education for Nigerian prisoners. Retrieved March 29, 2019 from https://www.nounportal.org.ng

16. Ndukwe, C., \& Iroko, N.C. (2014). Nigerian prison service and the challenges of social welfare administration: A study of Abakaliki prison. Journal of policy and Development Studies, 9(1). Retrieved from http://www.arabianjbmr.com

17. Obioha, E.E. (2011). Challenges and reforms in the Nigerian prisons system. Kamla-Raj Journal of Social Sciences, 27(2), 95-109. DOI:10.1080/09718923.2011.11892910

18. OECD. (2005). E-learning in tertiary education: Where do we stand? Retrieved April 25, 2019 from http://www.oecd-ibrary.org

19. Ogbaka, L.C., Ewelum, J.N., \& Apiti, A. (2017). Utilization of educational programmes in reformation of prison inmates in 
Nigeria. Asian Journal of Education and Training,3(2), 86-91. DOI: 10.20448/journal.522.2017.32.86.91

20. Ogidan, R., \& Jarri, S. (2012). Use of technology as support system for prison inmates in the national open university of Nigeria study center,Kirikiri-Lagos.Journal of the Open University Tanzania, 13(2),24-35.Retrieved from https://www.ajol.info/index.phd/

21. Olukayode, S.A. (2015). Challenges and prospects of e-learning at the national open university of Nigeria. Journal of Education and Learning, 9(3), 207-216. DOI: 10.11591/edulearn.v9i3.1728

22. Omoni, G. E. and Ijeh, S. U. (2009). Qualitative education for prisoners: A panacea to effective rehabilitation and integration into the society. Edo Journal of Counseling, 2(1), 27-37.

23. Onyekachi, J. (2016). Problems and prospects of administration of Nigerian prison: Need for proper rehabilitation of the inmates in Nigeria prisons. Journal for Tourism \& Hospitality 5, 228. http://doi: 10.4172/2167-0269.1000228

24. Otodo, I., \& Ugwuoke, K.A. (2015). The role of formal education in the rehabilitation and reintegration of prisoners in Nigeria: A case study of Jos prison, Nigeria.Journal for Studies in Management and Planning,1(11),43-54.

Retrievedfrom https://www.academia.edu/19338659/

25. Prison Studies Project. (2019). Why prison education? Retrieved from http://prisonstudiesproject.org/why-prison-education-programs

26. Smith, A.A. (2019, January, 16). Report shows benefit of prison education. Retrieved from http://www.insidehighered.com

27. Sunil,G.(2017,November,9).

Retrievedfrom http://www.elearningindustry.com

28. UNESCO (2002). Open and distance learning; Trends, policy and strategy consideration.

Retrieved from https://unesdoc.unesco.org/ark:/48223/pf0000128463

29. United Nations. (2009). Promotion and protection of human rights, civil, political, economic, social and cultural rights, including the rights to development: Report of the special rapporteur on the right to education, agenda item 3, UN general assembly. Retrieved from http://www2.ohchr.org

30. Valentina, A., \& Nelly, A. (2014). The role of e-learning, the advantages and disadvantages of its adoption in higher education. International Journal of Education and Research, 2(12). Retrieved from https://www.ijern.com/journal/2014/December-2014/34.pdf

31. Wagner, N., Hassanein, K. \& Head, M. (2008). Who is responsible for E- learning in Higher Education? A Stakeholders' Analysis. Educational Technology \& Society,11(3), 26-36. 